\title{
Isolation and Characterization of Well-Defined Silica-Supported Azametallacyclopentane: A Key Intermediate in Catalytic Hydroaminoalkylation Reactions
}

\author{
Bilel Hamzaoui, ${ }^{\text {a }}$ Jérémie D. A. Pelletier, ${ }^{\text {a }}$ Mohamad El Eter, ${ }^{a}$ Yin Chen, ${ }^{a}$ \\ Edy Abou-Hamad, ${ }^{\mathrm{a}}$ and Jean-Marie Basset ${ }^{\mathrm{a}, *}$ \\ a King Abdullah University of Science and Technology (KAUST), Physical Sciences and Engineering, KAUST Catalysis \\ Center, Thuwal 23955-6900, Saudi Arabia \\ Fax: (+966)-(0)12-802-1272; phone: (+966)-(0)12-808-0299; e-mail: jeanmarie.basset@kaust.edu.sa
}

Received: May 20, 2015; Revised: August 12, 2015; Published online: $\mathbf{\square}$ u, 0000

Supporting information for this article is available on the WWW under http://dx.doi.org/10.1002/adsc.201500484.

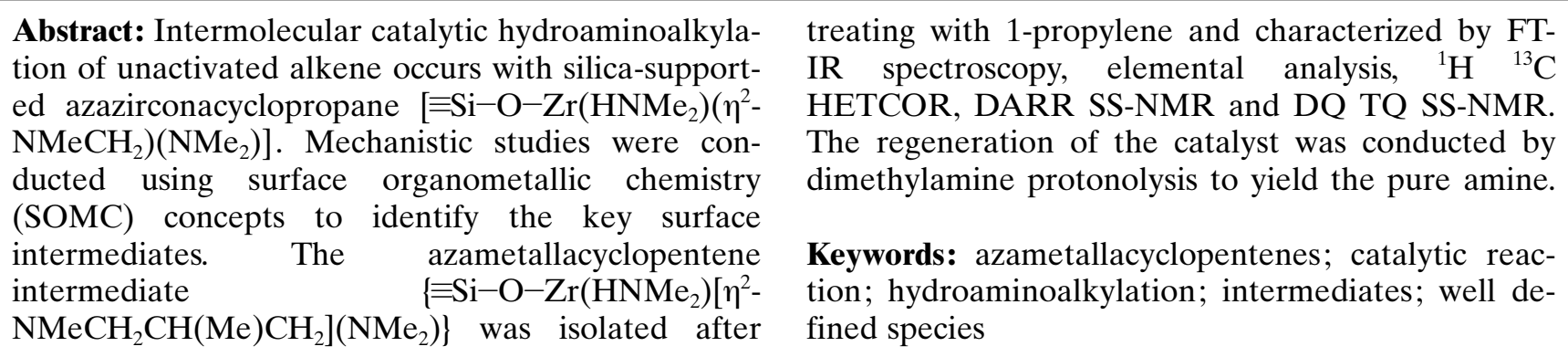

\section{Introduction}

Converting simple organic molecules to functionalized organic compounds is of great interest for academic and industrial research. ${ }^{[1]}$ Examples have been reported for cross-coupling, ${ }^{[2]}$ ring expansion ${ }^{[3]}$ and carbonylation $^{[4]}$ reactions. Catalytic hydroaminoalkylation reactions are of particular significance, as they provide a selective synthetic route to substituted amines from simple alkene feedstocks. ${ }^{[5]}$ The development of economically relevant heterogeneous catalysts would be a significant step to access a broad range of amines that are industrially important to the fine chemical industry. These reactions typically involve the addition of an $\alpha-\mathrm{C}-\mathrm{H}$ bond (of an amine) across an unsaturated $\mathrm{C}-\mathrm{C}$ bond [Eq. (1)]. ${ }^{[6]}$

Groups $4^{[7]}$ and $5^{[6 b, 8]}$ dimethylamido complexes have been well established as effective precatalysts for the $\alpha$-alkylation of dimethylamine with simple alkenes. ${ }^{[8,9]}$ High productivities on a broad range of substrates have been reported for electrophilic catalysts using sterically demanding amidate ${ }^{[6 a, 10]}$ or electron-withdrawing chloro ligands. ${ }^{[8 b]}$ The active species of the mechanism is commonly assumed to be an azametallacyclopropane because they promote alkylation

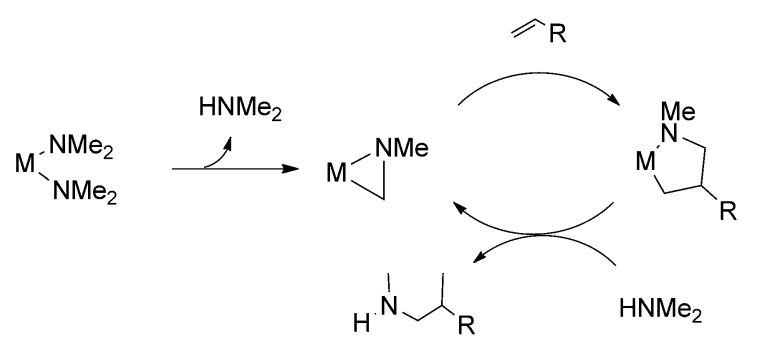

on the $\alpha$-position of the amine. A putative catalytic hydroaminoalkylation cycle has been proposed but has only been supported by a limited number of experiments. ${ }^{[8 b, 11]}$ In 1982, Nugent et al. investigated the $\alpha$-deuteration of dimethylamine by reversible $\alpha$-metallation-demetallation reaction. ${ }^{[12]}$ More recently, Hultzech $^{[8 c]}$ and Doye ${ }^{[11]}$ conducted kinetic studies on niobium- and titanium-based catalysts. Elimination of an amine from a metal bis(amide) precursor produces an intermediate that is classically assumed to be a metallaaziridine. ${ }^{[13]}$ Insertion of an olefin into the new metal-carbon bond generates a five-membered ring complex intermediate. Finally, the starting bis(amide) complex is regenerated through protonolysis by the 
amine substrate concomitantly with the release of the product. ${ }^{[1 \mathrm{a}, 8 \mathrm{a}, \mathrm{b}]}$

The application of zirconaaaziridine complexes toward organic transformations had been abundantly documented. ${ }^{[14]}$ Precedent examples for such a reactivity can be found in the works of Buchwald, ${ }^{[15]}$ Norton, ${ }^{[16]}$ Whitby, ${ }^{[17]}$ and Blagg two decades ago. ${ }^{[17 b, 18]}$ Zirconaaaziridines can generate, after work-up, functionalized amines by reaction with unsaturated $\mathrm{C}-\mathrm{C}$ bonds $^{[1 \mathrm{~b}]}$ (olefins and acetylenes) and $\mathrm{C}-\mathrm{X}$ bonds ${ }^{[1 \mathrm{~b}]}$ (aldehydes, carbonates ${ }^{[16 a, b, e, 19]}$ and imines ${ }^{[1 b]}$ ). This passes by the formation of a 5-membered zirconacycle through intermolecular ${ }^{[1 \mathrm{~b}]}$ or intramolecular ${ }^{[20]}$ insertion into the $\mathrm{Zr}-\mathrm{C}$ bond of the metallaaziridine. Buchwald ${ }^{[1 \mathrm{~b}]}$ and Whitby ${ }^{[17 \mathrm{~b}]}$ studied the intermolecular unsaturated hydrocarbon insertion into zirconaaziridines $^{[1 \mathrm{~b}]}$ that produce an amine with a vinyl or alkyl substituent at the $\alpha$ position (Scheme 1, A and

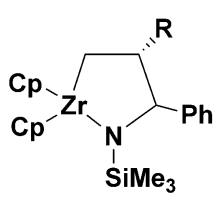

(A)

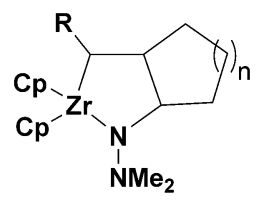

(B)

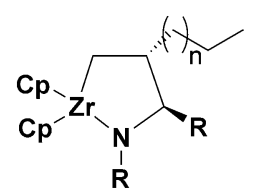

(C)
Scheme 1. Previously reported azazirconaacyclopentane molecular complexes.

C). Significant regioselectivity in 1,2-insertion fashion was observed for the formation of the corresponding five-membered metallacycles. Intramolecular insertion of olefins and acetylenes into the $\mathrm{Zr}-\mathrm{C}$ bonds of zirconaaziridines can lead to annulation reactions. Livinghouse showed that alkyl-, silyl-, and aryl-substituted carbon-carbon multiple bonds readily insert into the $\mathrm{Zr}-\mathrm{C}$ bonds of zirconaaziridines yielding cyclic products (Scheme 1, B). ${ }^{[20]}$ To note, mostly zirconium complexes with bulky and electron-rich cyclopentadienyl (Cp) ligands were employed. These studies examined the synthesis of the zirconaaziridine compounds. No catalytic screening for hydroaminoalkylation was reported then.

Metallaaziridine-based catalysts were reported only recently (since 2007) by various groups, including those of Schafer, ${ }^{[5 a, 6 b, 10 a, 21]}$ Doye ${ }^{[7 b, 11,22]}$ and Hartwig, ${ }^{[8 a, b]}$ as intermediates of the hydroaminoalkylation of alkenes. The insertion of the alkene into the $\mathrm{M}-\mathrm{C}$ bond of the metallaaziridine is supposed to be the $\mathrm{C}-$ $\mathrm{C}$ bond forming step. Schafer et al. prepared a bimetallic titanium species containing an azametallacyclopropane ligand bridging two metal centers. ${ }^{[7 a, 10 a]}$ In a separate experiment, they also observed the formation of a tantallaaziridine moiety from mono- and bisamidate tantalum complexes. ${ }^{[10 a]}$ Doye and Beckhaus reported the synthesis of titanaaziridine complexes starting from secondary $N$-methylamines and a sterically demanding $\operatorname{bis}\left(\eta^{5}: \eta^{1}\right.$-adamantylidenepentafulvene)titanium complex. ${ }^{[22 \mathrm{~b}]}$ Only recently has this family of compounds been investigated using surface organometallic chemistry (SOMC). SOMC has an unparalleled track record for the isolation and characterization of highly reactive species on the surfaces of metal oxides. ${ }^{[6,23]}$ For instance, we reported the isolation of the single-site well-defined surface species $\left[\equiv \mathrm{Si}-\mathrm{O}-\mathrm{Zr}\left(\mathrm{HNMe}_{2}\right)\left(\eta^{2}-\mathrm{NMeCH}_{2}\right)\left(\mathrm{NMe}_{2}\right)\right](\mathbf{1}) .{ }^{[24]}$

Herein, we fully characterize the structure of the prepared surface species by SS-NMR, elemental analysis and FT-IR spectroscopy. We have also identified the elementary steps in the intermolecular hydroaminoalkylation mechanism (Scheme 2) that is initiated from 1. We report the first isolation of the fivemembered metallacyclic intermediate supported on silica $\quad\left[\mathrm{Si}-\mathrm{O}-\mathrm{Zr}\left(\mathrm{HNMe}_{2}\right)\left[\eta^{2}-\right.\right.$ $\left.\left.\mathrm{NMeCH}_{2} \mathrm{CH}(\mathrm{Me}) \mathrm{CH}_{2}\right]\left(\mathrm{NMe}_{2}\right)\right\}$ (2). After dimethylamine protonolysis, $\mathbf{2}$ gave a hydroaminoalkylation product and regenerated $\mathbf{1}$ that can be reused several times.

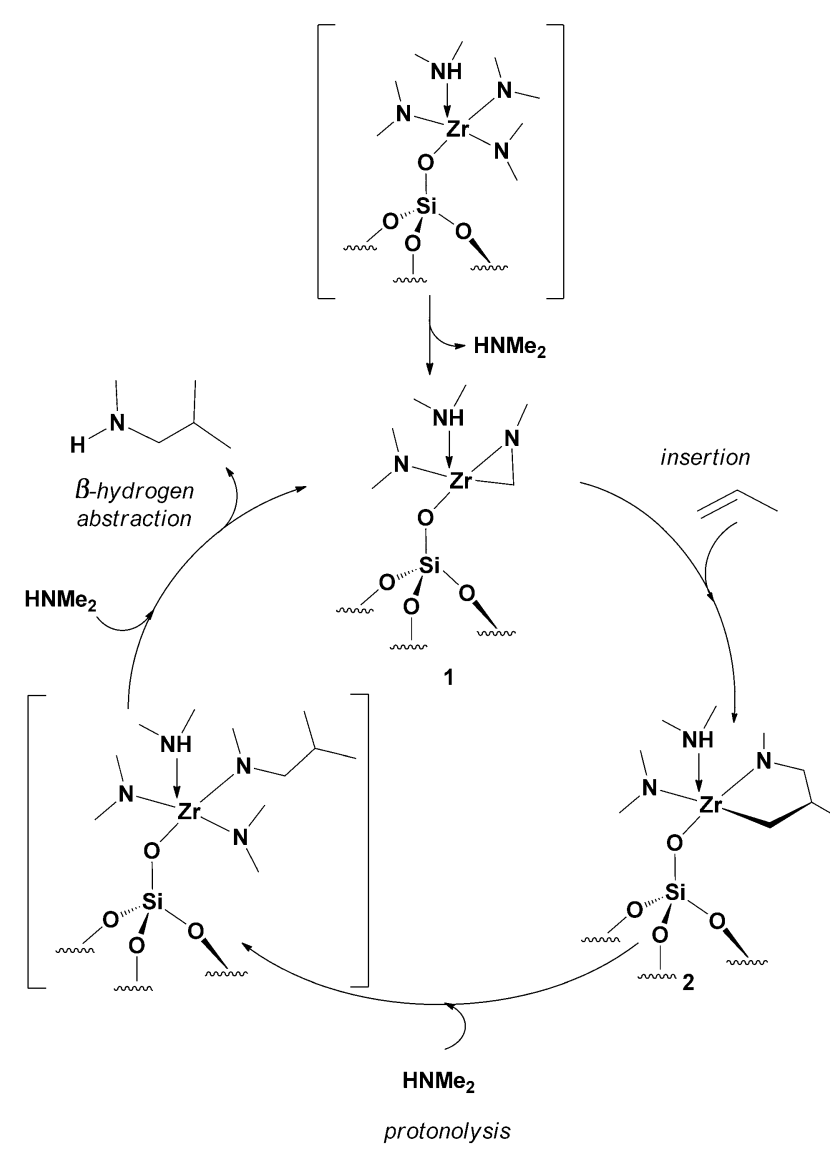

Scheme 2. Elementary steps of the intermolecular hydroaminoalkylation by the silica-supported zirconaziridine complex. 


\section{Results and Discussion}

Complex 1 was prepared according to a previously published procedure. ${ }^{[2]}$ After treatment of $\mathbf{1}$ with pure propylene $\left(0.6 \mathrm{bar}, 20 \mathrm{~h}\right.$ and $\left.150^{\circ} \mathrm{C}\right)$, a yellow powdery 2 was formed and was collected after evacuation $\left(10^{-4}\right.$ mbar at ambient temperature for $\left.1 \mathrm{~h}\right)$. Comparison of the FT-IR spectra of $\mathbf{1}$ and $\mathbf{2}$ reveals a change in the envelope of bands related to alkyl vibrations $\left(3000-2800 \mathrm{~cm}^{-1}\right)$ with a notable increase of $v\left(\mathrm{CH}_{2}\right)$ at $2958 \mathrm{~cm}^{-1}$ (Figure 1, a and b).

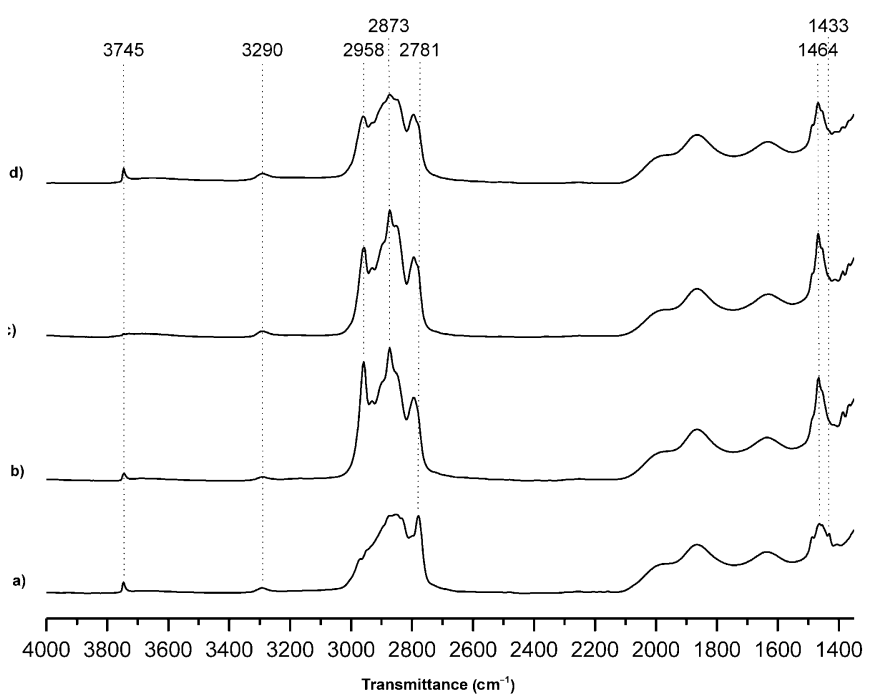

Figure 1. FT-IR spectra of a) 1, b) 2, c) 2 after treatment with $\mathrm{HNMe}_{2}\left(0.8\right.$ bar) at $150^{\circ} \mathrm{C}$ for $20 \mathrm{~h}$ followed by evacuation $\left(10^{-4}\right.$ mbar $)$ overnight, d) $\mathbf{2}$ after evacuation $\left(10^{-4}\right.$ mbar $)$ and heating at $150^{\circ} \mathrm{C}$ for $20 \mathrm{~h}$.

Elemental analysis gives $2.71 \% \mathrm{Zr}, 3.26 \% \mathrm{C}$ and $1.37 \% \mathrm{~N}$ with a ratio of $\mathrm{Zr} / \mathrm{C} / \mathrm{N}=1.0 / 9.1 / 3.2 \pm 1.0$ (theoretical ratio 1/9/3) (see the Supporting Information, Table S1). This ratio strongly suggests that one molecule of propylene has been incorporated by $\mathbf{1}$. To verify the insertion of propylene into $\mathbf{1}$, we used SSNMR of ${ }^{1} \mathrm{H},{ }^{13} \mathrm{C}$, DQ and TQ to fully assign $\mathbf{1}$ as in our previous report ${ }^{[17]}$ (see also the Supporting Information, Figure S1).

The ${ }^{1} \mathrm{H}$ SS-NMR spectrum of 2 (Figure 2, A) exhibits two major signals at 1.2 and $2.9 \mathrm{ppm}$ and two minor overlapping signals at 1.7 and $2.0 \mathrm{ppm}$. The most intense peak at $2.9 \mathrm{ppm}$ is reminiscent of that seen previously at $2.4 \mathrm{ppm}$ in $\mathbf{1}$ that was assigned to the $\mathrm{NCH}_{3}$ group in aminomethyl ligands (four methyl groups in 1and 2). The other three peaks clearly represent the more complex hydrocarbon motif around the zirconium centre in $\mathbf{2}$ compared to $\mathbf{1}$. The ${ }^{13} \mathrm{C}$ SSNMR spectrum (Figure 3, A) of $\mathbf{2}$ is consistent with less equivalent carbons, with four signals detected at $18,26,36$ and $58 \mathrm{ppm}$. The resonance at $36 \mathrm{ppm}$ was significantly more intense than the others, which can

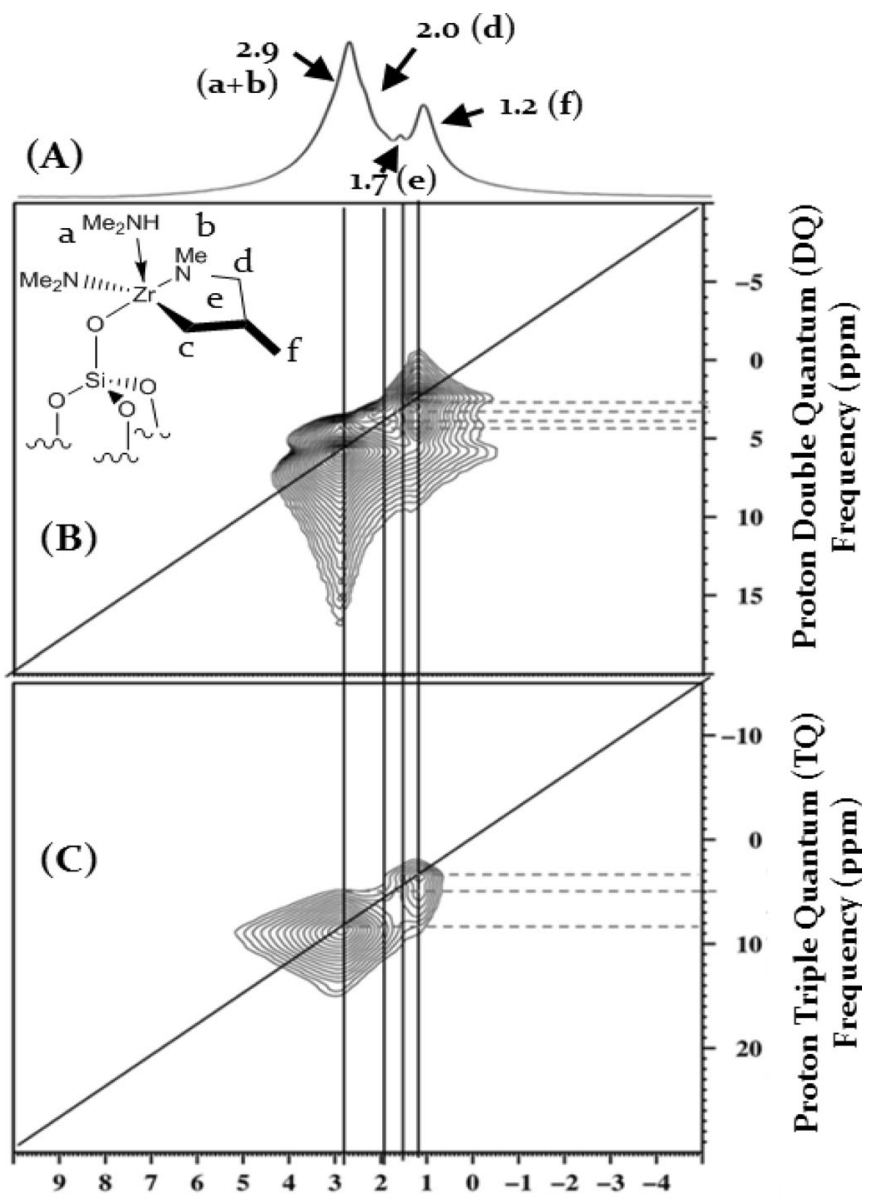

Proton Single Quantum Frequency (ppm)

Figure 2. (A) ${ }^{1} \mathrm{H}$ MAS NMR of 2, (B) and (C) 2D contour plots of the aliphatic region of the DQ and TQ proton SSNMR correlation spectra of $\mathbf{2}$ (see the Supporting Information for details).

be explained by the five aminomethyl fragments. This interpretation is compatible with multiple-quantum 2D experimental spectra of 2 that reveal autocorrelations in double-quantum (DQ) and triple-quantum (TQ) frequencies (Figure 2, B and C) for signals at $2.9 \mathrm{ppm}$. In addition, the $2 \mathrm{D}{ }^{1} \mathrm{H}^{13} \mathrm{C}$ HETCOR NMR spectrum (Figure 3, B) of 2 shows a correlation between the carbon peak at $36 \mathrm{ppm}$ and the proton peak at $2.9 \mathrm{ppm}$. Referring to the assignments proposed for $\mathbf{1}$, similar fragments ${ }^{[4 c]}$ can be attributed to these two peaks in dimethylamine $\mathrm{HN}\left(\mathrm{CH}_{3}\right)_{2}$ and dimethylamide $\mathrm{N}\left(\mathrm{CH}_{3}\right)_{2}$ ligands (labeled as a) and the methyl amide $\mathrm{N}\left(\mathrm{CH}_{3}\right)$ fragment (labeled as b) (Figure 2).

Signals at $18 \mathrm{ppm}\left({ }^{13} \mathrm{C}\right)$ and $1.2 \mathrm{ppm}\left({ }^{1} \mathrm{H}\right)$ correlate in the $2 \mathrm{D}{ }^{1} \mathrm{H}{ }^{13} \mathrm{C}$ HETCOR NMR spectrum (Figure 3 , B); both have chemical shifts consistent with a methyl fragment. The methyl assignment is validated by the autocorrelation at $1.2 \mathrm{ppm}$ in $\mathrm{DQ}$ and $\mathrm{TQ}$ frequencies (Figure 2, B and C). 


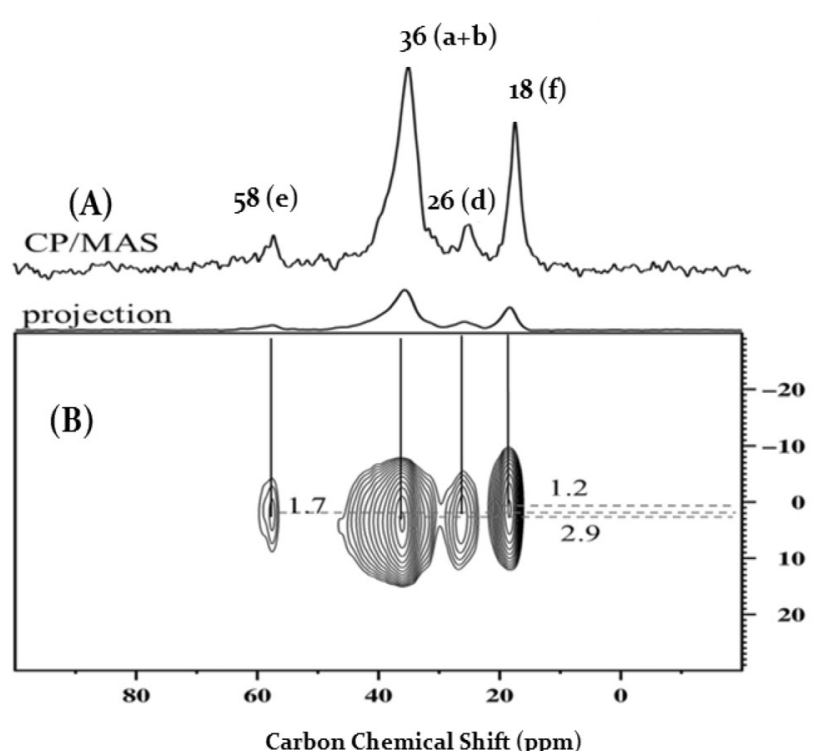

Figure 3. (A) $1 \mathrm{D}{ }^{13} \mathrm{C} \mathrm{CP} / \mathrm{MAS} \mathrm{NMR}$, (B) $2 \mathrm{D}$ contour plot of the aliphatic region of ${ }^{1} \mathrm{H}{ }^{13} \mathrm{C}$ HETCOR NMR spectrum of 2 (see the Supporting Information for details).

These signals are more shielded than (a) and (b), which is attributed to a $\mathrm{CH}_{3}$ (f) bonded to an alkyl fragment. The minor peak at $1.7 \mathrm{ppm}$ displays no auto-correlation in DQ or TQ frequencies (Figure 2, $\mathrm{B}$ and $\mathrm{C}$ ), while the peak at $2.0 \mathrm{ppm}$ shows an autocorrelation only in the DQ experiments; these can be assigned to $\mathrm{CH}$ and $\mathrm{CH}_{2}$, respectively. A strong correlation is observed between the proton peak at $1.7 \mathrm{ppm}$ and the carbon peak at $58 \mathrm{ppm}$ (Figure 3, B). These signals can be attributed to $\mathrm{CH}$ (e). Similarly, the carbon resonance at $26 \mathrm{ppm}$ correlates with that of the proton at $2.0 \mathrm{ppm}$ and is assigned to $\mathrm{CH}_{2}$ (d). The absence of $\mathrm{CH}_{2}$ (c) may be due to the low concentration of 2 . To increase the amount of zirconium on the surface, the synthesis of $\mathbf{2}$ was reproduced using $\mathrm{SBA}_{15}$ dehydroxylated at $700^{\circ} \mathrm{C}$. The carbon peak corresponding to $\mathrm{CH}_{2}$ (c) was observed at $63 \mathrm{ppm}$ in the ${ }^{13} \mathrm{C}$ CP/MAS NMR spectrum (see Figure 4). It correlates with the new protons peak at $2.2 \mathrm{ppm}$ in the $2 \mathrm{D}{ }^{1} \mathrm{H}^{13} \mathrm{C}$ HETCOR NMR (Figure 4). The resonance at $63 \mathrm{ppm}$ is indicative of a carbon in the $\alpha$-position of the zirconium center. ${ }^{[22 b, 25]}$ It is known that the signal of such a methylene carbon is difficult to detect in the solid state given its low abundance and highly restricted mobility. ${ }^{[26]}$ Examples of NMR characterization of related molecular complexes were documented; a ${ }^{13} \mathrm{C}$ chemical shift $(\delta=$ $66.2 \mathrm{ppm}$ ) has been reported as a characteristic signal of the $\mathrm{TiCH}_{2}$ group of titanaaziridine complexes; ${ }^{[22 \mathrm{~b}]}$ the corresponding ${ }^{1} \mathrm{H}$ signal has been observed between 1.13 and $2.62 \mathrm{ppm}$. In another report by Buchwald,${ }^{[1 b]}$ the $\mathrm{ZrCH}_{2}$ group gave ${ }^{1} \mathrm{H}$ signals in the range of 1.08 to 2.07 , slightly lower than that observed for 2 (2.2 ppm). The ${ }^{13} \mathrm{C}$ signals for $\mathrm{ZrCH}_{2}$ and $\mathrm{ZrCH}_{2} \mathrm{CH}$

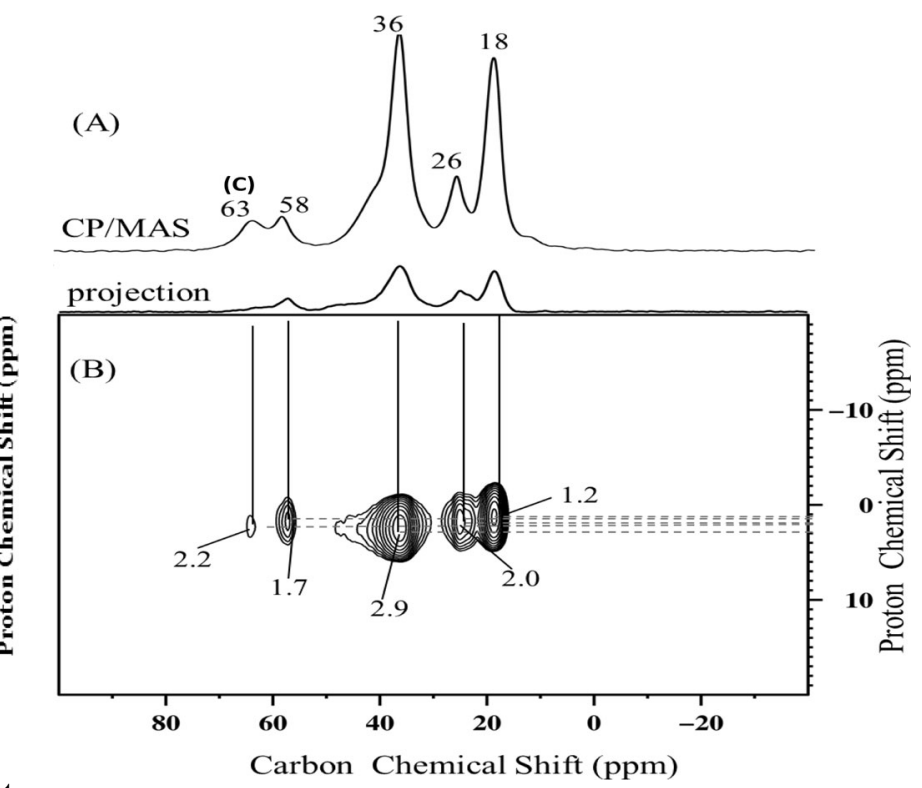

Figure 4. (A) $1 \mathrm{D}{ }^{13} \mathrm{C} \mathrm{CP} / \mathrm{MAS} \mathrm{NMR}$, (B) $2 \mathrm{D}$ contour plot of the aliphatic region of ${ }^{1} \mathrm{H}{ }^{13} \mathrm{C}$ HETCOR NMR spectrum of 2 on $\mathrm{SBA}_{15-700}$ (see the Supporting Information for details).

were not assigned unambiguously but were between 53.96 and $74.73 \mathrm{ppm}$. These values are roughly compatible with our own finding (58 and $63 \mathrm{ppm}$ ). It is noteworthy that the zirconium complexes prepared by Doyes and Buchwald were both based on cyclopentadienyl ligands, hence with a higher electron count than 2 (16 against 10 electrons).

${ }^{13} \mathrm{C}-{ }^{13} \mathrm{C}$ spin-diffusion correlation with DARR (dipolar-assisted rotational resonance) was performed to examine through-space correlations between the carbons in 2 (Figure 5). We observed a correlation be-

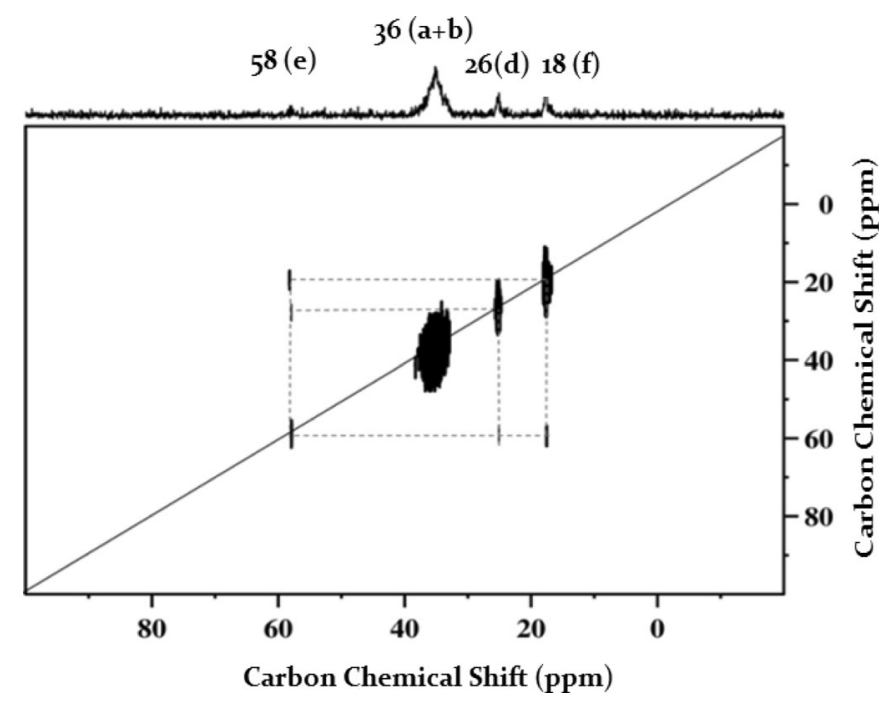

Figure 5. 2D ${ }^{13} \mathrm{C}{ }^{13} \mathrm{C}$ spin-diffusion with DARR of (2) (see the Supporting Information for details). 
tween signals at $58 \mathrm{ppm}$ in the tertiary $\mathrm{CH}$ (e) and signals at 18 and $26 \mathrm{ppm}$ in $\mathrm{CH}_{3}$ (f) and $\mathrm{CH}_{2}$ (d), respectively. No correlations were evident between the latter two; this is direct evidence that (e) is directly bonded with (f) and (d).

The carbon peak at $36 \mathrm{ppm}$ evidences the logical intensification of the autocorrelation because of its distance from the other carbons. Furthermore, space correlations in DQ (Figure 2, B) and TQ (Figure 2, C) spectra between the $\mathrm{CH}_{3}$ (f) protons at $1.2 \mathrm{ppm}$ and the protons at 1.7 and $2.0 \mathrm{ppm}$ that correspond with tertiary $\mathrm{CH}(\mathrm{e})$ and secondary $\mathrm{CH}_{2}$ (d) confirm the vicinity of these carbons. All these data support the structure of 2 as $\equiv \mathrm{Si}-\mathrm{O}-\mathrm{Zr}\left(\mathrm{HNMe}_{2}\right)\left[\eta^{2}\right.$ $\left.\left.\mathrm{NMeCH}_{2} \mathrm{CH}(\mathrm{Me}) \mathrm{CH}_{2}\right]\left(\mathrm{NMe}_{2}\right)\right\}$. This structure differs from 1 by its extended azametallacycle (3- vs. 5-) portion. By isolating 2, we were able to provide direct evidence that the hydroaminoalkylation mechanism includes the 1,2-insertion of olefin into the metalcarbon bond. These results were confirmed by a GCFID blank run on N,2-dimethylpropan-1-amine where we observed one peak at $4.5 \mathrm{mn}$ (Supporting Information, Figure S4b). By this same analytical method, the retention time was measured to be the same as that for the product observed after the reaction of $\mathbf{2}$ with dimethylamine $\left(0.8\right.$ bar) at $150^{\circ} \mathrm{C}$ for $20 \mathrm{~h}$ (Supporting Information, Figure S4a).

For catalytic hydroaminoalkylation testing, a mixture of one equivalent of propylene and an excess of dimethylamine ${ }^{[27]}$ was added to $\mathbf{1}$ at $150^{\circ} \mathrm{C}$ for $20 \mathrm{~h}$; $N$-methylisobutylamine was detected as the reaction product [Eq. (2)].

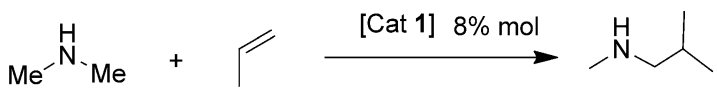

We attempted to monitor the reaction progress by comparing the evolution of propene quantities using GC-FID. The yield of the reaction was about $22 \%$ after $20 \mathrm{~h}$. Using a minor excess of the propylene compared to the dimethylamine resulted in a similar yield around $25 \% .{ }^{[28]}$

The catalytic reactivity of $\mathbf{1}$ for hydroaminoalkylation was tested in a complementary experiment using a small amount of $\mathbf{1}(100 \mathrm{mg})$ in a Schlenk vessel $(250 \mathrm{~mL})$. The powder was contacted sequentially with gases, vacuum and/or heating. The reaction was followed by FT-IR spectroscopy under an inert argon atmosphere (Figure 1). Complex $\mathbf{1}$ was contacted with propene $(0.8$ bar $)$ to generate 2 . After evacuation under $10^{-4}$ mbar for $1 \mathrm{~h}, \mathbf{2}$ was heated under a mixed atmosphere of dimethylamine $(0.8 \mathrm{bar})^{[27]}$ at $150^{\circ} \mathrm{C}$ for $20 \mathrm{~h}$. The FT-IR spectrum (Figure 1, c) of the product collected after a rapid evacuation shows no significant differences in the pattern of $v(\mathrm{C}-\mathrm{H})$ vibrations with that of $\mathbf{2}$. Note that the bands assigned to isolated silanols at $3747 \mathrm{~cm}^{-1}$ observed in both $\mathbf{1}$ and 2 disappeared, suggesting that they likely interact with the products via hydrogen bonding. GC and GCMS found comparable amounts of $N$-methylisobutylamine and dimethylamine in the gas phase after the reaction (see the Supporting Information, Figure $\mathrm{S} 3 \mathrm{~b}$ ). The compound was then evacuated under $10^{-4} \mathrm{mbar}$ at $150^{\circ} \mathrm{C}$ for $20 \mathrm{~h}$, and the FT-IR (Figure 1, d) spectrum shows the peak corresponding to the silanols at $3745 \mathrm{~cm}^{-1}$ with similar intensity to that in Figure 1, a and b. These data support that the hydroaminoalkylation of propylene occurs but that only small amounts of the $N$-methylisobutylamine produced remain physisorbed on the silica surface after the reaction. This was confirmed with a blank experiment, ${ }^{[29]}$ where $\mathrm{SiO}_{2-700}$ was treated with the evolved gas phase (containing $N$-methylisobutylamine and dimethylamine). Comparing treated silica and $\mathrm{SiO}_{2-700}$ (see the Supporting Information, Figure S8) IR spectra revealed an envelope in the $\mathrm{CH}$ stretching region between $2959-2808 \mathrm{~cm}^{-1}$. This result validates the hypothesis that physisorption of the amine onto silica occurs in the absence of a grafted complex (Figure 1, d). The catalyst was reused three times by repeating the following steps: i) heating with propylene $\left(0.8\right.$ bar) at $150^{\circ} \mathrm{C}$ for $20 \mathrm{~h}$, ii) evacuation under $10^{-4} \mathrm{mbar}$ and iii) heating with dimethylamine $\left(0.8\right.$ bar) at $150{ }^{\circ} \mathrm{C}$ for $20 \mathrm{~h}$. The components in the gas phases were monitored by $\mathrm{GC}$ after each sequence (see the Supporting Information, Figures S3a, $\mathrm{S} 3 \mathrm{~b}$ and $\mathrm{S} 3 \mathrm{c}$ ). After three runs, $N$-methylisobutylamine continued to be obtained, although, in declining amounts, likely due to the decomposition of the catalyst.

The catalytic performance of $\mathbf{2}$ remains modest in comparison with its tantalum-based homogenous counterparts. ${ }^{[\mathrm{Ba}]}$ Note that zirconium catalysts have only been reported at very low activity levels for this reaction. ${ }^{[8 \mathrm{a}]}$ Potentially this explains the relative stability of azazirconacyclopentane $\mathbf{2}$ that allows for its isolation and characterization. It is well known that a silica surface enhances catalysis and stabilizes the active species. ${ }^{[23 \mathrm{~b}]}$

\section{Conclusions}

Our investigation agrees with the accepted mechanism of the hydroaminoalkylation reaction, which includes the isolation of elusive azazirconacyclopentane $\mathbf{2}$ as a key intermediate. Its precursor $\mathbf{1}$ was prepared by grafting $\mathrm{Zr}\left(\mathrm{NMe}_{2}\right)_{4}$ onto the surface of $\mathrm{SiO}_{2-700}$. Azazirconacyclopentane (2) was obtained after controlled insertion of propylene (Scheme 1). The initial complex (1) can be regenerated by introducing excess 
gaseous dimethylamine, which led to the opening of the metallacyclic fragment and the release of $N$-methylisobutylamine.

Complex 1 can undergo further cycles but also shows catalytic activity when using a mixture of propene and amine. These results confirm that supporting zirconium complexes onto silica is viable for catalytic heterogeneous hydroaminoalkylation. Yet the catalytic performances remain modest but are encouraging to pursue towards the development of better heterogeneous catalysts to be used in broader range of processes.

\section{Experimental Section}

\section{General}

All experiments were performed in a controlled atmosphere (i.e., argon or nitrogen). Syntheses and treatments of the surface species were carried out by using high-vacuum lines $\left(<10^{-5}\right.$ mbar $)$ and glove-box techniques. Elemental analyses were performed at the Microanalytisches Labor Pascher and KAUST Analytical Corelab. $\mathrm{Zr}\left(\mathrm{NMe}_{2}\right)_{4}$ was purchased from Sigma-Aldrich. FT-IR spectra were recorded on a Nicolet 6700 FT-IR spectrometer equipped with a cell designed for in situ experiments with $\mathrm{CaF}_{2}$ windows. Typically, sixteen scans were accumulated for each spectrum (resolution of $4 \mathrm{~cm}^{-1}$ ). One dimensional ${ }^{1} \mathrm{H}$ MAS and ${ }^{13} \mathrm{C}$ CP/MAS SSNMR spectra were recorded on a Bruker AVANCE III spectrometer operating at $400 \mathrm{MHz}$ for ${ }^{1} \mathrm{H}$, with a conventional double-resonance $4 \mathrm{~mm} \mathrm{CP/MAS} \mathrm{probe.} \mathrm{The} \mathrm{samples}$ were introduced under argon into zirconia rotors, which were then tightly closed. The spinning frequency was set to $17 \mathrm{KHz}$ for ${ }^{1} \mathrm{H}$ and to $10 \mathrm{KHz}$ for ${ }^{13} \mathrm{C}$ spectra. NMR chemical shifts are reported with respect to TMS as an external reference for ${ }^{1} \mathrm{H}$ and ${ }^{13} \mathrm{C}$. For $\mathrm{CP} / \mathrm{MAS}{ }^{13} \mathrm{C}$ NMR experiments, the following sequence was used: 900 pulse on the proton (pulse length $=2.4 \mathrm{~s}$ ) followed by a cross-polarization step with a contact time of typically $2 \mathrm{~ms}$, and finally acquisition of the ${ }^{13} \mathrm{C}$ signal under high-power proton decoupling (see the Supporting Information for details).

\section{Preparation of $\equiv \mathrm{Si}-\mathrm{O}-\mathrm{Zr}\left(\mathrm{NMe}_{2}\right)\left(\mathrm{HNMe}_{2}\right)-$ $\left(\mathrm{NMeCH}_{2}\right)(\mathbf{1})$}

In a double Schlenk vessel, $264.85 \mathrm{mg}$ of $\mathrm{Zr}\left(\mathrm{NMe}_{2}\right)_{4}$ in a slight excess (1.1 equiv.) with respect to the amount of surface accessible silanols ( $0.3 \mathrm{mmol}$ silanols groups per gram) was reacted with $3 \mathrm{~g}$ of $\mathrm{SiO}_{2-700}$ at room temperature in pentane for $1 \mathrm{~h}$. After filtration and four washing cycles, all volatile compounds were evaporated and the white solid was dried for $1 \mathrm{~h}$ under dynamic vacuum $\left(<10^{-5} \mathrm{mbar}\right)$ conditions.

\section{Preparation of $\equiv \mathrm{Si}-\mathrm{O}-\mathrm{Zr}\left(\mathrm{HNMe}_{2}\right)\left[\eta^{2}-\right.$ $\left.\mathrm{NMeCH}_{2} \mathrm{CH}(\mathrm{Me}) \mathrm{CH}_{2}\right]\left(\mathrm{NMe}_{2}\right)$ (2)}

In a glass reactor $(230 \mathrm{~mL})$, an excess of dried propylene gas (0.8 mbar) was reacted with $1 \mathrm{~g}$ of (1). The reaction was heated with the gradient from room temperature to $150^{\circ} \mathrm{C}$ $\left(1^{\circ} \mathrm{C}\right.$ per minute) and then at $150^{\circ} \mathrm{C}$ for $24 \mathrm{~h}$. After the reaction, the remaining gas was analyzed by GC-GC-MS and found to contain only propylene, which was evacuated for $1 \mathrm{~h}$ under dynamic vacuum $\left(<10^{-5} \mathrm{mbar}\right)$ conditions.

\section{Alkylation of Dimethylamine with Propylene}

In a glove-box, a glass reactor tube $(230 \mathrm{~mL})$ was charged with (1) $(840 \mathrm{mg}, 0.22 \mathrm{mmol}, 0.08$ equiv.). The reactor was evacuated using a high-vacuum line. $2.81 \mathrm{mmol}$ propylene ( 0.3 bar, 1 equiv.) were introduced and condensed by cooling with liquid nitrogen. Next, $\mathrm{HNMe}_{2}+\mathrm{H}_{2}$ (0.4 mbar) was added. After closing the reactor, the mixture was heated $\left(150^{\circ} \mathrm{C}\right)$ for $20 \mathrm{~h}$ and then was cooled to $22^{\circ} \mathrm{C}$. After the reaction, the gas phase was analyzed by GC-FID and GC-MS.

\section{Acknowledgements}

We thank King Abdullah University of Science and Technology for continuous support.

\section{References}

[1] a) H. Tsurugi, K. Yamamoto, H. Nagae, H. Kaneko, K. Mashima, Dalton Trans. 2014, 43, 2331-2343; b) S. L. Buchwald, B. T. Watson, M. W. Wannamaker, J. C. Dewan, J. Am. Chem. Soc. 1989, 111, 4486-4494; c) I. Omae, J. Organomet. Chem. 2007, 692, 2608-2632; d) R. D. Broene, S. L. Buchwald, Science 1993, 261, 1696-1701.

[2] G. D. Frey, C. P. Reisinger, E. Herdtweck, W. A. Herrmann, J. Organomet. Chem. 2005, 690, 3193-3201.

[3] D. Sole, L. Vallverdu, X. Solans, M. Font-Bardia, J. Bonjoch, Organometallics 2004, 23, 1438-1447.

[4] H. Takahashi, J. Tsuji, J. Organomet. Chem. 1967, 10, 511-517.

[5] a) E. Chong, J. W. Brandt, L. L. Schafer, J. Am. Chem. Soc. 2014, 136, 10898-10901; b) S. Raoufmoghaddam, Org. Biomol. Chem. 2014, 12, 7179-7193.

[6] a) J. Dorfler, S. Doye, Angew. Chem. 2013, 125, 18511854; Angew. Chem. Int. Ed. 2013, 52, 1806-1809; b) P. Eisenberger, R. O. Ayinla, J. M. P. Lauzon, L. L. Schafer, Angew. Chem. 2009, 121, 8511-8515; Angew. Chem. Int. Ed. 2009, 48, 8361-8365.

[7] a) J. A. Bexrud, P. Eisenberger, D. C. Leitch, P. R. Payne, L. L. Schafer, J. Am. Chem. Soc. 2009, 131, 2116-2118; b) R. Kubiak, I. Prochnow, S. Doye, Angew. Chem. 2009, 121, 1173-1176; Angew. Chem. Int. Ed. 2009, 48, 1153-1156; c) R. Kubiak, I. Prochnow, S. Doye, Angew. Chem. 2010, 122, 2683-2686; Angew. Chem. Int. Ed. 2010, 49, 2626-2629; d) T. Preuss, W. Saak, S. Doye, Chem. Eur. J. 2013, 19, 3833-3837; e) D. Jaspers, W. Saak, S. Doye, Synlett 2012, 2098-2102.

[8] a) S. B. Herzon, J. F. Hartwig, J. Am. Chem. Soc. 2007, 129, 6690-6691; b) S. B. Herzon, J. F. Hartwig, J. Am. Chem. Soc. 2008, 130, 14940-14941; c) A. L. Reznichenko, K. C. Hultzsch, J. Am. Chem. Soc. 2012, 134, 33003311; d) A. L. Reznichenko, T. J. Emge, S. Audorsch, E. G. Klauber, K. C. Hultzsch, B. Schmidt, Organome- 
tallics 2011, 30, 921-924; e) F. R. Zhang, H. B. Song, G. F. Zi, Dalton Trans. 2011, 40, 1547-1566.

[9] P. W. Roesky, Angew. Chem. 2009, 121, 4988-4991; Angew. Chem. Int. Ed. 2009, 48, 4892-4894.

[10] a) J. M. P. Lauzon, L. L. Schafer, Dalton Trans. 2012, 41, 11539-11550; b) Z. X. Zhang, J. D. Hamel, L. L. Schafer, Chem. Eur. J. 2013, 19, 8751-8754; c) P. Garcia, P. R. Payne, E. Chong, R. L. Webster, B. J. Barron, A. C. Behrle, J. A. R. Schmidt, L. L. Schafer, Tetrahedron 2013, 69, 5737-5743.

[11] I. Prochnow, P. Zark, T. Muller, S. Doye, Angew. Chem. 2011, 123, 6525-6529; Angew. Chem. Int. Ed. 2011, 50, 6401-6405.

[12] W. A. Nugent, D. W. Ovenall, S. J. Holmes, Organometallics 1983, 2, 161-162.

[13] E. Chong, P. Garcia, L. L. Schafer, Synthesis 2014, 46, 2884-2896.

[14] A. Cummings, A. Tunge, R. Norton, Top. Organomet. Chem. 2005, 10, 1-39.

[15] a) R. B. Grossman, W. M. Davis, S. L. Buchwald, J. Am. Chem. Soc. 1991, 113, 2321-2322; b) S. L. Buchwald, R. B. Nielsen, J. Am. Chem. Soc. 1988, 110, 3171-3175; c) S. L. Buchwald, R. B. Nielsen, J. C. Dewan, Organometallics 1988, 7, 2324-2328.

[16] a) D. A. Gately, J. R. Norton, P. A. Goodson, J. Am Chem. Soc. 1995, 117, 986-996; b) J. X. Chen, J. A. Tunge, J. R. Norton, J. Org. Chem. 2002, 67, 4366-4369; c) T. V. Lubben, K. Plossl, J. R. Norton, M. M. Miller, O. P. Anderson, Organometallics 1992, 11, 122-127; d) J. A. Tunge, C. J. Czerwinski，D. A. Gately, J. R. Norton, Organometallics 2001, 20, 254-260; e) J. A. Tunge, D. A. Gately, J. R. Norton, J. Am. Chem. Soc. 1999, 121, 4520-4521.

[17] a) N. Coles, M. C. J. Harris, R. J. Whitby, J. Blagg, Organometallics 1994, 13, 190-199; b) M. C. J. Harris, R. J. Whitby, J. Blagg, Tetrahedron Lett. 1995, 36, 4287-4290; c) J. M. Davis, R. J. Whitby, A. Jaxachamiec, Tetrahedron Lett. 1992, 33, 5655-5658; d) J. M. Davis, R. J. Whitby, A. Jaxachamiec, Tetrahedron Lett. 1994, 35, 1445-1448.
[18] a) N. Coles, R. J. Whitby, J. Blagg, Synlett 1990, 271272; b) N. Coles, R. J. Whitby, J. Blagg, Synlett 1992, $143-145$.

[19] D. A. Gately, J. R. Norton, J. Am. Chem. Soc. 1996, 118, 3479-3489.

[20] M. Jensen, T. Livinghouse, J. Am. Chem. Soc. 1989, 111, 4495-4496.

[21] E. Chong, L. L. Schafer, Org. Lett. 2013, 15, 6002-6005.

[22] a) J. Dörfler, T. Preuß, A. Schischko, M. Schmidtmann, S. Doye, Angew. Chem. 2014, 126, 8052-8056; Angew. Chem. Int. Ed. 2014, 53, 7918-7922; b) M. Manßen, N. Lauterbach, J. Dörfler, M. Schmidtmann, W. Saak, S. Doye, R. Beckhaus, Angew. Chem. 2015, 127, 44584462; Angew. Chem. Int. Ed. 2015, 54, 4383-4387.

[23] a) J. M. Basset, S. L. Scott, A. Choplin, M. Leconte, F. Quignard, C. Santini, A. Theolier, NATO Adv. Sci. Inst. Ser. 1993, 398, 39-49; b) Y. Chen, E. Abou-hamad, A. Hamieh, B. Hamzaoui, L. Emsley, J. M. Basset, J. Am. Chem. Soc. 2015, 137, 588-591.

[24] a) M. El Eter, B. Hamzaoui, E. Abou-Hamad, J. D. A. Pelletier, J. M. Basset, Chem. Commun. 2013, 49, 46164618; b) B. Hamzaoui, M. El Eter, E. Abou-Hamad, Y. Chen, J. D. A. Pelletier, J. M. Basset, Chem. Eur. J. 2015, 21, 4294-4299.

[25] a) Y. Takahashi, N. Onoyama, Y. Ishikawa, S. Motojima, K. Sugiyama, Chem. Lett. 1978, 525-528; b) C. Airoldi, D. C. Bradley, G. Vuru, Transitition Metal Chemistry 1979, 4, 64-64.

[26] M. Beaudoin, S. L. Scott, Organometallics 2001, 20, 237-239.

[27] For all our experiments, $\mathrm{Me}_{2} \mathrm{HN}$ gas was generate by hydrogenation in situ of $\mathrm{Me}_{2} \mathrm{NLi}$ at $150^{\circ} \mathrm{C}$. After drying and deoxygenation using a gas trap $(3 \AA$ molecular sieves + copper oxide), the excess of $\mathrm{H}_{2}$ remained mixed with the dimethylamine. A blank test was conducted and showed that $\mathbf{2}$ was unreactive to pure hydrogen in the same conditions.

[28] The amount of dimethylamine introduced in the experiment can be only roughly estimated as it was generated in situ.

[29] L. D. White, C. P. Tripp, J. Colloid Interface Sci. 2000, $232,400-407$. 


\section{FULL PAPERS}

8 Isolation and Characterization of Well-Defined SilicaSupported Azametallacyclopentane: A Key Intermediate in Catalytic Hydroaminoalkylation Reactions

Adv. Synth. Catal. 2015, 357, 1-8

Bilel Hamzaoui, Jérémie D. A. Pelletier, Mohamad El Eter, Yin Chen, Edy Abou-Hamad, Jean-Marie Basset*

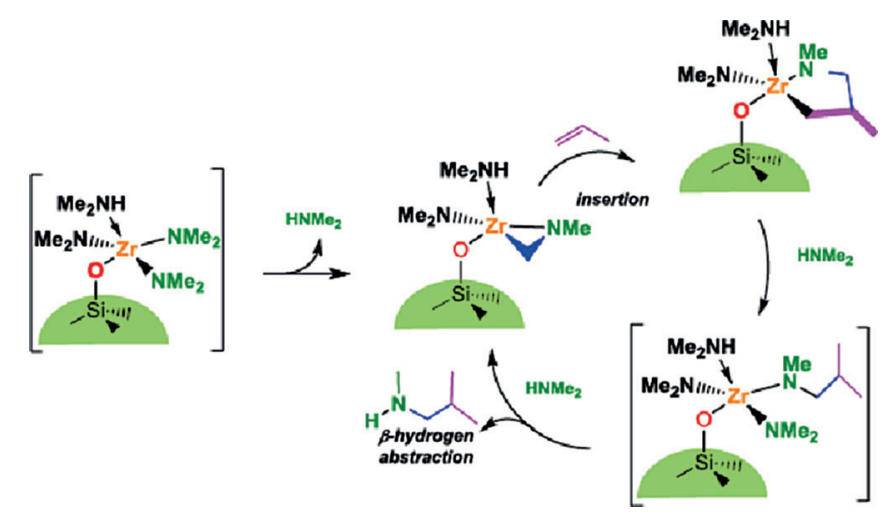

